\title{
Utjecaj digitalizacije na generacijski jaz - od bejbibumersa do generacije Z
}

Prethodno priopćenje _ DOI 10.22522/cmr20190143_ primljeno 6. veljače 2018. UDK: 004-042.3

$316.48: 316.346 .36$

\section{Maja Fistrić}

Millenium promocija, Zagreb, Hrvatska.

E-adresa:majafis@gmail.com

\section{Sažetak}

Tisućama godina društveno se međudjelovanje gradilo isključivo na komunikaciji licem u lice. S dolaskom i razvojem komunikacijskih tehnologija, kao i razvojem interneta, pojavili su se novi oblici društvenosti koji ne odgovaraju svakom tipu čovjeka. Prostorna i vremenska udaljenost više ne čine nikakvu prepreku da poslana poruka ne bude primljena u realnom vremenu tisućama kilometara daleko, a ti novonastali proizvodi i sustavi stvaraju svakim danom svoju, sve širu, publiku i vlastita pravila komuniciranja i obrasce socijalne komunikacije. Svrha ovog rada jest prikazati učinak procesa digitalizacije i globalizacije na različite generacije - bejbibumerse, generaciju X, generaciju Y i generaciju Z. Primjenom metode ankete istražili smo razlike između generacija kada je riječ o poznavanju digitalnih medija (novih medija). Osim toga, istražili smo i razlike u upotrebi novih medija te u načinu dolaska do željenih informacija.

Ključne riječi: digitalni jaz, bejbibumersi, generacija X, generacija Y, generacija Z 


\section{Digitalni jaz}

Digitalni jaz odlikuje mogućnost pristupa internetu. Prema tome, ljude možemo podijeliti na one koji taj pristup imaju i one kojiga nemaju, bez obzira na njihovu opću socioekonomsku podjelu. „Razlikovanje onih koji imaju i onih koji nemaju pristup internetu dodaje još jednu temeljnu podjelu već postojećim izvorima nejednakosti i društvene isključenosti u složenoj interakciji koja, čini se, povećava prazninu između obećanja informacijskog doba i njegove sive realnosti za većinu ljudi širom svijeta“ (Castells, 2003a, str. 271).

Generacijski jaz, između ostalog, očituje se i geografski i međuljudski, prožima sve međuljudske odnose na globalnoj, državnoj, poslovnoj i privatnoj razini. Prvenstveno, on označava različitu mogućnost između pojedinaca, kućanstava, tvrtki, država koje su na različitim socioekonomskim razinama u odnosu na njihovu mogućnost pristupa informacijskim novitetima i tehnološkim inovacijama, kao i mogućnost pristupa internetu za poslovne i privatne aktivnosti. Digitalni jaz, dakle, nije samo geografski određen između dvije države, već se očituje i kroz stanje unutar jedne snažnije ili slabije razvijenije države, kroz slojeve društva, populacije različitih dobnih skupina, spolova, kao i između profesija (Soar, Swindell, Tsang, 2011, str. 237). Upravo je zato na početku rečeno da ga je možda najjednostavnije definirati kao mogućnost „imati ili ne imati“, ne uključujući samo pristup internetu, već i svijest o mogućnosti napredovanja putem što razvijenije tehnologije i informacijskih znanosti.

Prema trenutnim podacima svjetskog stanovništva, 3,5 milijardi svjetske populacije koristi informacijske i tehnološke inovacije, dok je za 3,9 milijardi ljudi korištenje istih onemogućeno zbog nemogućnosti edukacije, infrastrukture ili nekih drugih razloga (Hina, 2016). U Republici Hrvatskoj omjer je korisnika i onih koji ne koriste internet podjednak svjetskim brojkama, s gotovo 3,7 milijuna korisnika mreže (Raknić, 2016). Očekivano, među najpogođenijim korisnicima na kojima je digitalni jaz najočitiji su starije osobe ukazujući tako na pojavu generacijskog jaza, osobe s invaliditetom i osobe slabijeg imovinskog stanja koje zbog vlastitih financijskih (ne)mogućnosti nemaju pristup tehnološkim inovacijama (Norris, 2001, str. 68).

Gotovo proporcionalno povezani rast između digitalizacije i generacijskog jaza, najočitiji je upravo na primjeru dobnih skupina. Razlike između generacija ne moraju biti više desetljeća, dovoljno je pogledati u nasumično izabrani razred i vidjeti razliku $\mathrm{u}$ informacijskoj pismenosti profesora koji se upravo susreću s uvođenjem e-imenika u 
Republici Hrvatskoj i učenika koji se zatvorenih očiju snalaze na touchscreen tipkovnici (Aniko, 2015, str. 2). Ono što je za generaciju Y bio presedan poput pametnih telefona, online kupnje ili društvenih mreža, za pripadnike generacije $\mathrm{Z}$ je to najnormalnija svakodnevica. Ove i još mnoge druge razlike među dobnim skupinama, baš poput inovacija, rapidno se razvijaju pa više razlika nije vidljiva između dva desetljeća, već svega između nekoliko godina.

\subsection{Prevladavanje generacijskog jaza}

Pri prevladavanju generacijskog jaza, prvotno se treba naglasiti važnost uloge političara, odnosno donošenja političkih odluka i regulatorne reforme. Vlade trebaju prepoznati potencijal u gospodarskoj aktivnosti koja može proizaći iz elektroničke trgovine. Nadalje, neke zemlje trebaju biti usmjerene na smanjenje digitalnog jaza pojačanjem i proširenjem infrastrukture, kako bi se informacije lakše širile i kako bi se poboljšale vještine pojedinaca i radnika. Najveći dio pažnje treba biti posvećen javnim ustanovama, kao što su knjižnice, škole, sveučilišta i slično, gdje pojedincima treba biti omogućen pristup internetu bez ikakvih troškova, kako bi mogli razviti vlastite vještine (OECD, 2001, str. 19).

Sam proces prevladavanja digitalne podjele veoma je složen i zahtijeva trostruki angažman - ekonomski, društveni i politički. Čimbenici koji uzrokuju digitalnu nejednakost su ekonomski, obrazovni, društveni, tehnološki i politički, no isto tako su ti čimbenici od velike važnosti prilikom prevladavanja digitalne nejednakosti. Svaka država treba donositi nove zakone i odredbe kojima bi se olakšalo i poticalo unapređenje informacijskih i komunikacijskih tehnologija te omogućilo svim građanima da se informiraju, bez obzira na to gdje se nalaze. Kao društveni aspekt prevladavanja digitalne nejednakosti treba educirati građane o važnosti usvajanja vještina korištenja modernih tehnologija, te ohrabriti, u ovome kontekstu, ugrožene skupine, kao što su na primjer osobe u starijoj životnoj dobi i osobe s niskim stupnjem obrazovanja, na korištenje novih tehnologija.

Mjere potrebne za rješavanje problema digitalne nejednakosti odnose se uglavnom na opremu i pristup internetu. Međutim, manje se pozornosti posvećuje načinu i kvaliteti korištenja novih tehnologija i pravilnom postupanju s informacijama. Zaključno, pristup informacijskim izvorima, posebice internetu i sredstvima komunikacije, podržava zdravlje i obrazovanje, kao i kulturni i ekonomski razvitak društva. Diseminacija informacija omogućuje sudjelovanje u cjeloživotnom učenju i obrazovanju, što je od velike važnosti za sve građane. Informacije o svjetskim postignućima daju svim građanima pravo 
na sudjelovanje u razvoju svoga društvenog okruženja. Jednaki pristup kulturnom i znanstvenom nasljeđu čovječanstva pravo je svake osobe i ono pomaže promidžbi učenja i razumijevanja bogatstva i raznolikosti svijeta, ne samo za sadašnju generaciju, već i za one koje dolaze. Knjižnice su dugo bile temeljni i najvažniji posrednici u poticanju i razvoju ljudskih vrijednosti. Danas velik broj knjižnica djeluju digitalno i njihove digitalne usluge otvaraju nova vrata k svijetu znanja i informacija, povezujući kulture i pritom rušeći geografske i društvene granice. Stoga su one odgovor za prevladavanje generacijskog jaza (IFLA/UNESCO manifest za digitalne knjižnice, 2016).

\section{Društvene mreže}

U svijetu koji postaje sve digitaliziraniji nemoguće je poreći važnost i utjecaj koji u njemu imaju društvene mreže. Posljednjih nekoliko godina postale su vrlo popularne usluge koje korisnicima omogućavaju stvaranje privatnog, javnog ili polujavnog osobnog profila u okruženju s ograničenim pristupom, prikazivanje popisa ostalih korisnika $\mathrm{s}$ kojima dijele vezu, te sagledavanje i upravljanje vlastitim vezama i tuđim vezama unutar sustava (Grbavac, Grbavac, 2014, str. 208). Nastale su rapidnim razvojem interneta, a broj korisnika povećava se svakim satom. Danas je pristup društvenim mrežama omogućen putem pametnih telefona i tableta, šireći utjecaj brojnih propagandnih poruka i mišljenja o društvenim zbivanjima na sve širi auditorij. Rast društvenih mreža temelji se upravo na omogućavanju mobilnosti jer vrijeme provedeno na svim dostupnim oblicima medija s pristupom internetu premašuju vremensko trajanje ijedne druge dnevne aktivnosti pojedinca (Grbavac, Grbavac, 2014).

Teško je predvidjeti budući razvoj, odnosno hoće li društvene mreže opstati i u kojem obliku, no nakon desetljeća inovacija čini se da će one, barem u nekom obliku, biti permanentne. Stranicama za društvene mreže sada se daje mogućnost komuniciranja u stvarnom vremenu čineći ih tako najpoželjnijim platformama u službi informiranja i komuniciranja, a istovremeno se na ostale internetske stranice sa sadržajem koji stvara korisnik dodaju mogućnosti društvenih mreža (Christakis, 2010, str. 257).

Kako raste popularnost društvenih mreža, tako raste i broj njihovih članova koji su u prosjeku stariji i iz različitih društvenih slojeva. Generacija koja je odrasla upravo s i na društvenim mrežama je ona najmlađa generacija, tzv. generacija Z. Besplatna mogućnost komunikacije uz neograničeno dijeljenje brojnih sadržaja najprivlačniji su faktori koji 
utječu na korištenje društvenih mreža među mladima koji se ovim putem mogu predstaviti vršnjacima i svijetu u željenom svjetlu. To je generacija koja je naviknuta imati svaku informaciju odmah dostupnom bez pretjeranog truda u njihovu pronalaženju.

Uzevši u obzir pozitivne strane društvenih mreža poput brisanja vremenskih i prostornih ograničenju u svrhu povezivanja ljudi diljem svijeta u realnom vremenu, veća i lakša mogućnost za uspostavljanje interakcije kao i mogućnost saznavanja brojnih informacija i sadržaja, moramo uzeti u obzir i one negativne utjecaje. Pojavom društvenih mreža, koliko god uspješne bile $u$ interakciji ljudi, proizvoda i usluga, gubimo određenu sferu vlastite privatnosti, nailazimo na probleme digitalnog identiteta (digitalnu reprezentaciju stvarne osobe) koji se javlja među većinom mlađom populacijom koja ne zna na koji se način najbolje predstaviti i pritom gubi svoj vlastiti identitet, stvarajući virtualni identitet uz ogromni potencijal razvitka ovisnosti o društvenim mrežama.

\section{Od bejbibumersa do generacije z}

Svako društvo u svim najrazličitijim kulturama prolazi kroz određene promjene, razvojne, sociološke, ekonomske i političke. Dakako, svaka generacija ima vlastita obilježja i karakteristike, koje su drugoj generaciji ponekad i potpuna nepoznanica. U razdoblju od sredine 20. stoljeća na prijelazu u 21. stoljeće možemo govoriti i o svojevrsnim generacijskim kategorijama. One okupljaju pojedince rođene $u$ točno određenom vremenskom razdoblju i sličnih su životnih navika, odgoja, načina komuniciranja, potrošačkih karakteristika i karakteristika provođenja vremena. Brojni autori (Zemke, Raines, Filipczak, 2000) slažu se da postoje određene osnovne generacijske kategorije:

bejbibumersi - to su ljudi koji su rođeni nakon 2. svjetskog rata, od 1946. do 1960. godine,

generacija X - rođeni između 1960. i 1980. godine,

generacija Y - rođeni između 1981.i 1995. godine,

generacija Z - rođeni nakon 1995. godine i

prema futuristu, demografu i govorniku TEDx-a Marku McCrindleu - generacija Alfa rođeni između 2010. i 2025. godine. 


\subsection{Bejbibumersi - rođeni između 1946. i 1960. godine}

Nazvani po očekivanom velikom natalitetnom skoku nakon svjetske krize razmjera kakav je bio Drugi svjetski rat, tzv. bejbibumersi rođeni su u razdoblju rapidnog ekonomskog uzleta većine zemalja koje su se sustavno brže ili nešto sporije oporavljale nakon ogromnih gubitaka i šteta, što ljudskih, što financijskih. Upravo oni, rođeni u razdoblju od prve neratne godine 1946. do kraja šezdesetih godina 20. stoljeća, bili su dijelom najveće, najprogresivnije i najobrazovanije generacije ikada u povijesti čovječanstva. Generaciju koju je obilježila borba za politička prava manjina i drugih rasa u Americi, legalan svijet brojnih narkotika, masovni prosvjedi protiv aktualnih i prijetećih ratova vođenih na brojnim glazbenim festivalima promovirajući mir i jednakost.

Zanimljivo, unutar samih bejbibumersa nailazimo na dvije grupe. Rani predstavnici generacije bejbibumersa rođeni do početka 60 -ih godina, odrasli su okruženi pričama o Vijetnamskom i Hladnom ratu, glazbi u stilu Boba Dylana i „hipijevskoj“ subkulturi. Naspram njih, kasnija generacija bejbibumersa bliža je generaciji X, odrastajući uz diskoglazbu i igrajući brojne videoigre koje ranijim pripadnicima nisu bile dostupne. Pripadnici bejbibumersa, kao i pripadnici tradicionalista, ljudi rođenih prije 1945., čiji je život obilježio Drugi svjetski rat, imaju izražene radne navike i etiku, ali s različitim motivima. Rad ne predstavlja isključivo zaslugu i privilegiju, već je to sredstvo kojim se dolazi do boljeg socioekonomskog statusa i ugleda (Crowe i sur., 2016, str. 8). Tehnološka dostignuća ove generacije odlikuju se najrasprostranjenijom inovacijom ikada - televizorom u boji, kao i slijetanjem prvog čovjeka na Mjesec. Želja za tehnološkom inovacijom i napretkom začeta je tijekom Drugog svjetskog rata čiju ekspanziju doživljava upravo tijekom odrastanja ove generacije. Ljudi su orijentirani jedni na druge, isključivo koristeći osobni kontakt pri komunikaciji ili sve više dostupne fiksne telefone. Pripadnici ove generacije socijalizirat će se s ljudima s kojima dijele zajedničke interese po pitanju glazbe, filma, ostalih umjetnosti, novaca, ali i načina života (McNamara, 2015).

Bez obzira što je ovo jedna od karakteristika bejbibumersa, može se reći da su društveni mediji ovakvo ponašanje ne samo potaknuli, već i učinili normalnim kod svih današnjih generacija. Uistinu smo svjedoci različitih grupa koje se zbližavaju samo zato jer dijele iste ili slične interese, na primjer čitanje knjiga, gledanje filmova ili televizijskih serija. Same društvene mreže omogućuju ljudima grupiranje prema osobnim interesima, a članove određenih Facebook grupa ili onih $\mathrm{u}$ forumskim zajednicama osobe s kojom su u komunikaciji primarno ne zanimaju. Ono što se traži u takvim zajednicama je zajednički interes koji je uobičajeno jedina i glavna tema njihovih razgovora. 


\subsection{Generacija X - rođeni između 1960. i 1980. godine}

Odrasli okruženi automobilima, televizijskim programom punim vijesti o odvijanju Hladnog rata i utrke $u$ tehnološkim, gospodarskim i vojnim inovacijama, generacija $\mathrm{X}$ udaljava se od načela prethodne generacije. Snažan utjecaj ostaje na generaciji koja odrasta $\mathrm{u}$ napetosti neprestano tinjajućeg rata, pogođenoj brojnim ekonomskim krizama izazvanih upravo politički sve nestabilnijim uvjetima. Generacija X svjedoči padu Berlinskog zida i nepovjerenju jedne države prema drugoj, kao i narušenim međuljudskim odnosima u brojnim socijalističkim zemljama gdje susjed sa susjedom polako zbog određenih političkih okolnosti prestaje komunicirati (Selwyn, 2009, str. 2). Mlađoj populaciji tako preostaje samostalno odrasti, većinom s jednim roditeljem zbog povećanja broja obitelji pogođenih razvodom, na videoigrama, prvoj e-pošti, kao i vlastitoj interpretaciji događaja u okolini. Lako se može zaključiti kako su pripadnici ove generacije, za razliku od prethodne, introvertirane osobe koje su odane svojem poslu, a ne kolektivu niti nadređenom. Školuju se radi onog što postižu karijerom i financijskom moći, ne kako bi služili višem kolektivu i njihovim ciljevima. Preferiraju komunikaciju uživo s drugim osobama, iako sve obaveze stavljaju ispred takvih radnji, opravdavajući to prezauzetošću poslovnim obavezama. Većinom posjeduju osobno računalo i shvaćaju mogućnosti i prednosti povezivanja svijeta radi što bržeg, kvalitetnijeg i jednostavnijeg prijenosa informacija koji do prije nekoliko godina nije bilo moguće niti zamisliti, stoga možemo reći da razmišljaju globalno. Odlikuju ih ponešto drugačije karakteristike nego prethodnu generaciju, uvjetovane upravo ranije navedenim okolnostima. Prije svega su pragmatični, informirani putem svih dostupnih medija interesirajući se podjednako za podatke iz bliže okoline, kao i globalne informacije te su tehnološki iznimno pismeniji. Za razliku od bejbibumersa, generacija $\mathrm{X}$ ne živi da bi radila, već naprotiv, radi da bi živjela oslanjajući se isključivo na sebe umjesto na tim i kolektiv. Trenutno se događa smjena generacija na rukovodećim pozicijama kako diljem svijeta, tako i kod nas između osoba rođenih prije i nakon 1960. godine (Kindrick Patterson, 2007, str. 19).

Ono što je važno napomenuti za generaciju $\mathrm{X}$ je to da su oni prva generacija koja je razvila globalni pogled na svijet. Kako danas svi, htjeli mi to sebi priznati ili ne, živimo u globalnom selu, može se reći da je ova generacija prva koja je iskusila dobrobiti međusobno povezanog svijeta. Pripadnici ove generacije su prvi koji su smatrali da je svaka točka na Zemlji dostupna. Jednostavno mogu otputovati, zaposliti se i započeti novi život na drugom kraju svijeta. Njihovo globalno razmišljanje i želja za različitosti na radnom mjestu govori 
u prilog tomu da su mnogi pripadnici ove generacije težili radu u međunarodnim tvrtkama ili u gradovima u kojima nisu odrasli (Zmeke, Raines, Filipczak, 2000). No, negativna strana za zaposlene pripadnike generacije $\mathrm{X}$ leži u financijskim mogućnostima. Naime, zbog stagnacije gospodarstva i svjetskog tržišta, nisu bili u mogućnosti monetizirati svoja znanja i prednosti koje im je dala globalizacija. U poslovnom komuniciranju, ovu generaciju karakterizira činjenica da vole dobiti povratne informacije za ono što su napravili na radnom mjestu. Za razliku od prethodnih generacija, ovo je prva generacija koja radno mjesto ne povezuje s pisanjem ili pisanom komunikacijom. Naravno, to ne znači da ona za njih ne postoji, već generacija $\mathrm{X}$ voli slati elektroničku poštu, umjesto da gubi vrijeme na pisanje dopisa, pisama ili dokumenata u poslovnoj komunikaciji (Zmeke, Raines, Filipczak, 2000). U ovoj generaciji vidljiv je postepeni prijelaz u načinu komunikacije u poslovnom okruženju, koji se i danas primarno temelji na računalno-posredovanoj komunikaciji (Sezin Baysal Berkup, 2014, str. 221-222 prema Oh, Reeves, 2014).

\subsection{Generacija Y - rođeni između 1981. i 1995. godine}

Rođeni i odrasli u jednom od najturbulentnijih razdoblja u 20. stoljeću, generacija Y se na neki način približava svojim prethodnicima. Padom Berlinskog zida i otvaranjem vrata brojnih socijalističkih država kapitalizmu, diljem Europe osjeća se gotovo olakšanje. Generacija Y poprima odlike optimizma i socijalne osjetljivosti temeljene na iskustvu brojnih socioekonomskih i političkih nemira koje su osjetili direktno ili su ih uočili koristeći se sredstvima informiranja (Montana, Petit, 2008, str. 139). Upravo socijalna empatija, nekarakteristična za prethodnu generaciju X, dovodi do njihova snažnog razvitka komunikacijskih vještina pa ne čudi da upravo u ovoj generaciji internet doživljava svoju globalnu ekspanziju. Pripadnici ove generacije s internetom su se prvi put susreli kao djeca u pubertetskim godinama života te se može reći kako je on i te kako utjecao na njihov način razmišljanja i stavove (Levickaitè, 2010).

Upravo pod utjecajem globalizacije njihov vrijednosni sustav snažno je razvijen i tolerantniji od njihovih prethodnika, a usprkos izraženoj individualnosti naslijeđenoj od prethodne generacije, teže pripadnosti različitim umreženim grupama, stoga ne čudi rapidan porast broja internetskih foruma i portala na kojima pojedinci mogu samostalno sudjelovati pri kreiranju sadržaja (Levickaitè, 2010). Generacija Y i te kako je iskoristila sve mogućnosti, kako globalnog tržišta, tako i računalno-posredovane komunikacije u poslovnom svijetu, ali i uporabu interneta za različite svrhe. Lammiman i Syrett (2005) 
navode da generacija Y ispred svega cijeni i traži komfor i privatnost, kako u privatnom tako i poslovnom životu, iako to sve češće uključuje dobrovoljno izabrani samački život. Na poslu funkcioniraju prvenstveno kao indivude koje sudjeluju u radu organizacija, ali iskustvena preporuka drugih ljudi je ono na čemu temelje svoje povjerenje. Razumljivo je zašto preferiraju podjednako komunikaciju licem u lice kao i komunikaciju putem tekstualnih poruka, tzv. SMS-ova, i sve brojnijih društvenih platformi za slanje poruka. Iznimno su informatički pismeni, što više nije iznimka, nego pravilo, te su tolerantni, pouzdani (pogotovo prilikom provjere dobivenih informacija) i društveno osviješteni s ciljem da njihov individualan rad ipak služi svrsi šire zajednice (Watson, 2013, str. 4).

Najvidljiviji primjer su njihove potrošačke navike - od svih generacija najviše provode vremena u istraživanju cijene, kvalitete i podrijetla proizvoda i usluga (Gasser, Palfrey, 2008 , str. 167). Usluga mora biti brza, proizvod kvalitetan, ali prvenstveno odluku donose na temelju dobre preporuke iz bliže i šire okoline. Nekad je bilo dovoljno da tada najpopularnija filmska zvijezda reklamira određeni proizvod i on bi u trenu bio rasprodan. Danas je drugačije, a posebice kod pripadnika generacije Y. Može se reći kako su se njihove navike razvile sukladno tehnološkim dostignućima i uporabom tehnologije u prodaji. Kako bi se saznalo odakle neki proizvod dolazi ili koje su mu karakteristike, dovoljno je upisati ga u jednu od mnogobrojnih internetskih tražilica, a pripadnici generacije Y toga su i te kako svjesni.

\subsection{Generacija Z - rođeni nakon 1995. godine}

Najmlađa generacija, rođena tijekom prijelaza i poslije početka novog tisućljeća, nosi i druga popularna imena poput Face-generacija ili iPhone generacija. Odrastaju na mobilnim uređajima, tabletima, prijenosnim računalima umreženima putem društvenih mreža, $u$ doba 3D printanja namirnica i dijelova tijela. Globalna povezanost nikad nije bila snažnija, a informacijska i tehnološka pismenost nikada nisu bile na višoj razini. Živeći u virtualnoj stvarnosti, komunikaciju održavaju na identičan način - putem društvenih mreža. Generacija Z je naviknuta imati informaciju „na dlanu“, dostupnu u bilo kojem trenutku i na bilo kojem mjestu olakšavajući si pritom put do željenih podataka (Parks, 2013, str. 51). Evolucija društvenih igara dovodi nas do virtualnih igara. Istovremeno, sve su udaljeniji od prvih susjeda ili braće i sestara. Za razliku od svih prethodnih generacija, odlikuje ih sposobnost tzv. multitaskinga - mogućnosti obavljanja dva i više poslova istovremeno s vrlo impozantnim rezultatima (Enyon, Helsper, 2009, str. 2). Kao što ih zaprimaju, tako informacije i obrađuju - iznimno brzo i kvalitetno, težeći što pristupačnijem dolasku do 
samih podataka. Umjesto satisfakcije kolektiva, najvažnije je vlastito instant-zadovoljstvo i konzumeristički način života uz veliku tolerantnost na tuđe potrebe i različitosti. Živeći takvim stilom života, mladi su sve introvertiraniji, iznenađujuće konzervativniji, upravo zbog izgubljenih vrijednosti i težnji za povratkom na stari sustav promišljanja te su osjetno manje socijalno osjetljiviji (Prensky, 2001, str. 5).

Tehnologija je svakako potaknula i ubrzala stvaranje generacijskih razlika. Vjerojatno doba naprednih generacije na jedan od najvjerodostojnijih načina opisuje sljedeći citat: „Stiže generacija Y kojoj je jedna od najbitnijih karakteristika upravljanje protokom informacija. Mladi ljudi koji sjede za računalom i u isto vrijeme mogu obavljati nekoliko poslova, komunicirati, slušati glazbu, učiti matematiku, nemaju nikakav poremećaj, kao što se može čuti. (...) Generaciju Y ne zanima kako funkcionira tehnologija, oni žele što brži pristup mreži.“" (Krištofić, 2007, str. 166).

\subsection{Generacija Alfa - rođeni između 2010. i 2025. godine}

Iako su pripadnici ove generacije premladi i neće sudjelovati u istraživačkom dijelu rada, nužno je opisati tek nadolazeće generacije. O generaciji Alfa tek se nagađa kakva bi mogla biti, a zasad se sa sigurnošću govori da će obuhvatiti one rođene između 2010. godine i 2025. godine. Pojedini autori analizirali su nadolazeću generaciju i ponuđeno je nekoliko pretpostavki o pripadnicima te generacije. Naime, tvrdi se kako će oni biti najpoduzetnija generacija koja će se do tada pojaviti. To se objašnjava činjenicama da svaka nadolazeća generacija ima sve veći pristup informacijskim izvorima, ljudima i resursima koji su im potrebni za razvitak poslovanja. Čak se i predviđa kako će mnogi pripadnici ove generacije započeti svoje poslove prije desete godine života (Schawbel, 2014).

Tehnološki će generacija Alfa biti najnaprednija, a neće poznavati svijet bez društvenih mreža i društvenog umrežavanja. Sukladno s daljnjim razvitkom tehnologije, razvijat će se i nadolazeće generacije. Također se navodi da će ova generacija biti marketinški isplativa tek onim tvrtkama koje će svoje mrežne stranice prilagoditi isključivo mobilnim uređajima, s obzirom na to da se predviđa da će se generacija Alfa primarno koristiti mobilnim uređajima u komunikaciji, poslu, istraživanju, informiranju... Tako će tražiti mobilne aplikacije koje su izuzetno jednostavne za korištenje i vizualno atraktivne, a očekuje se i da će oni imati želju da se sama aplikacija podredi njihovim životnim potrebama i načinu života (Businessinsider.com, 2015).

1 Futurist, demograf i govornik TEdx-a Mark Mekkrindl vodi kampanju kojoj je cilj da sve rođene nakon 2010. godine nazove generacija Alfa. 
Generacija Alfa kupovinu će obavljati preko interneta. Predviđa se kako će upravo ova generacija najmanje komunicirati licem $u$ lice, a gotovo će u potpunosti njihova komunikacija biti računalno posredovana. Bez obzira na to, smatra se da će u toj generaciji ljudi dosegnuti vrhunac u međusobnom povezivanju. Iako će biti izuzetno povezani i drugi ljudi će im biti stalno dostupni, osjećat će se izolirani od svijeta. Pripadnici generacije Alfa bit će primarno potomci današnjih generacija X i Y. Odrastat će zaštićeno i pod utjecajem generacija svojih roditelja. Važno je znati kako se pripadnici generacije Y vole osjećati posebno i imati svrhu u svijetu. Ovu karakteristiku preuzet će (ili već i preuzima) i generacija Z i generacija Alfa, a kako će utjecaj njihovih roditelja imati važnu ulogu u njihovu odgoju pa čak i više od utjecaja društva ili prijatelja, marketinški stručnjaci će se u budućnosti morati prilagoditi ne samo pripadnicima generacije Alfa, već i generacijama njihovih roditelja jer su oni koje će prve pitati za savjet, osobito prilikom kupovine većih stvari poput kuće, stana ili automobila.

Pripadnici generacije Alfa bit će pretjerano samopouzdani, ali i spremniji za brojne rizike. Isto tako će se odlikovati natprosječnim obrazovanjem. Predviđa se da će online učenje za njih biti uobičajeno, duže će se obrazovati i sami će prilagođavati razine obrazovanja svojim osobinama i interesima. Oni s nižim platežnim mogućnostima morat će se obrazovati u online okruženju, dok će se oni iz bogatijih obitelji nastaviti obrazovati na sličan način kao danas, pohađajući sveučilišta. Nažalost, ono što nas u budućnosti čeka je i sve veći financijski jaz (Schawbel, 2014).

\section{Istraživanje}

U skladu s ciljem istraživanja, a to je dokazati utjecaj digitalizacije na generacijski jaz, postavljene su četiri hipoteze:

1. Bejbibumersi (rođeni između 1946.i 1960. godine) ne koriste pametne telefone za dolazak do informacija.

2. Postoji generacijski jaz između bejbibumersa i generacije Z što se očituje u načinu korištenja novih medija.

3. Generacija Y najviše vremena provodi online.

4. Generacija Z nije upoznata sa starom tehnologijom koja se koristila za vrijeme odrastanja ostalih generacija. 
U istraživanju je sudjelovalo 152 ispitanika pri čemu 38 ispitanika iz generacije bejbibumersa (rođeni između 1946. i 1960. godine), 39 ispitanika iz generacije X, 33 ispitanika iz generacije Y i 42 ispitanika iz generacije Z. Obuhvaćene su osobe svih životnih razdoblja, od školaraca i studenata do zaposlenih i nezaposlenih. Od ukupnog broja ispitanika, njih 86 je bilo ženskog spola, a ostatak je bio muškog spola.

Iz provedenog istraživanja možemo potvrditi da bejbibumersi ne koriste pametne telefone za dolazak do informacija. Od cjelokupnog broja ispitanih, samo 15 ispitanika, redom sve pripadnici bejbibumers generacije, ne posjeduje prijenosno računalo niti pristup internetu, uz zanimljivo, ali očekivano, izjašnjenje da ne posjeduju osnovno znanje rada na računalu. Tablet koristi puno manji broj ispitanika, oko njih 15, dok oni koji koriste internet ga u 90 \% slučajeva koriste svakodnevno.

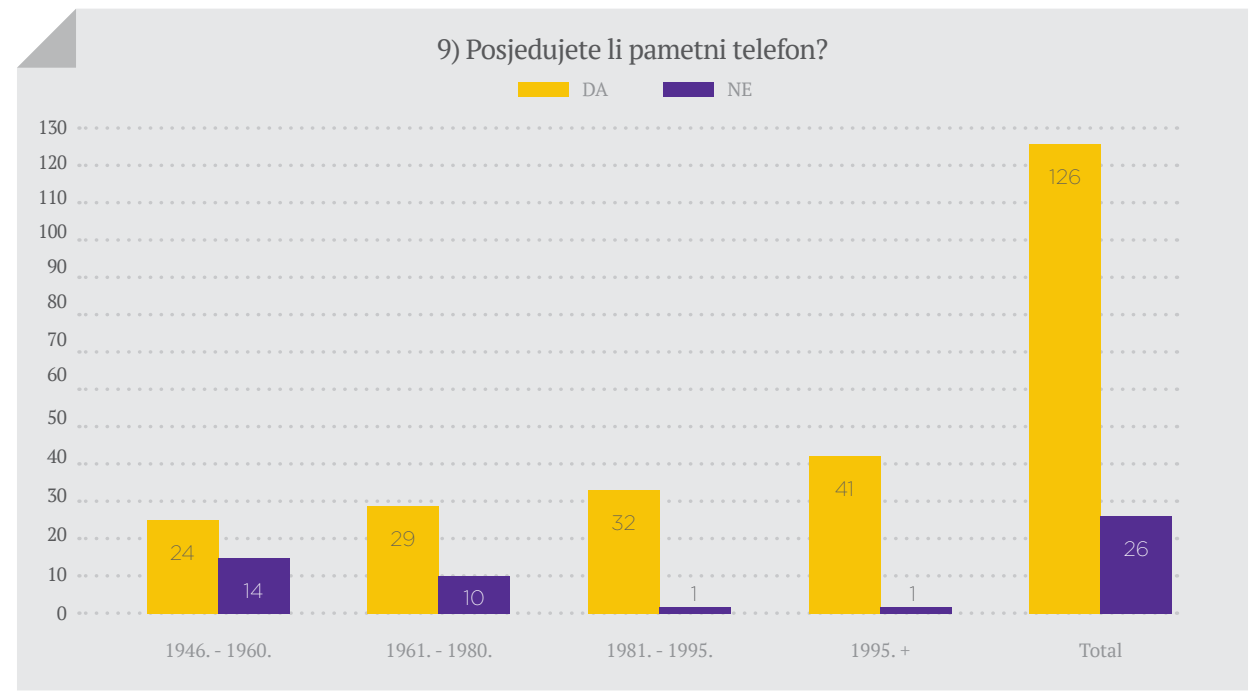

Grafikon 1. Posjedovanje pametnog telefona $(\mathrm{N}=152)$

Izvor dnevnog informiranja među pripadnicima generacijskih kategorija $\mathrm{Y}$ i Z isključivo je pametan telefon, dok je među pripadnicima generacije $\mathrm{X}$ i bejbibumersa glavni izvor informacija televizija. 


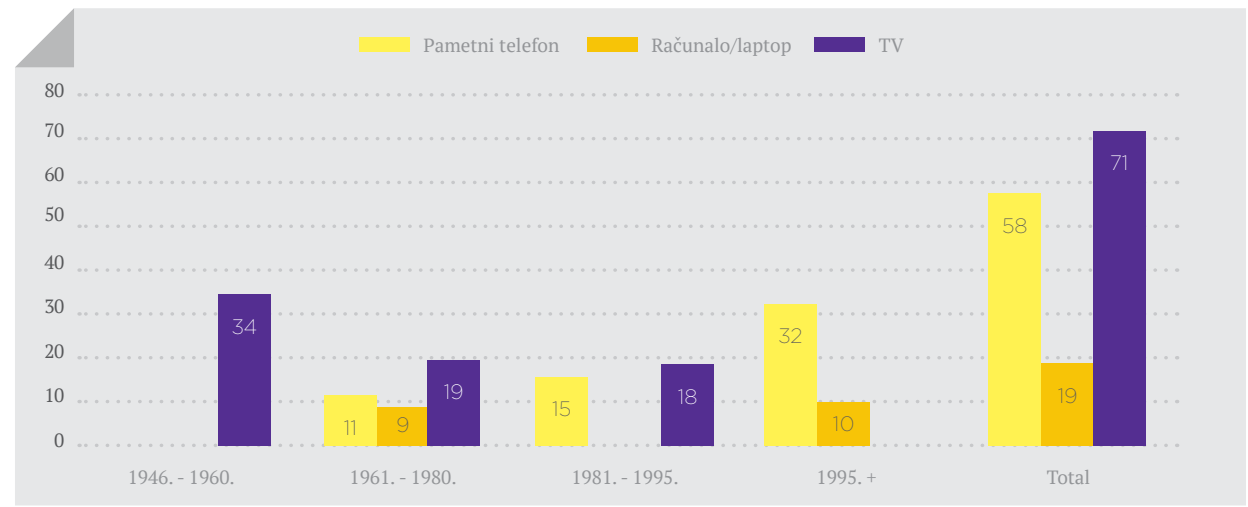

Grafikon 2. Izvor informiranja ( $\mathrm{N}=152)$

Istraživanjem smo također potvrdili da postoji generacijski jaz između bejbibumersa i generacije Z što se očituje u načinu korištenja novih medija. Naime, iz priloženih odgovora možemo zaključiti kako dio bejbibumersa koristi nove medije isključivo u svrhu traženja i čitanja vijesti. Suprotno od navedenih rezultata, generacija Z koristi nove medije za sve njima potrebne dnevne aktivnosti. Svi ispitanici, točnije njih 42 , koriste nove medije za dopisivanje i slušanje glazbe. Četrdeset ispitanika putem novih medija kontaktira rodbinu, a tri četvrtine ispitanika putem novih medija traži i čita općenite podatke ili podatke potrebne za posao ili studiranje.

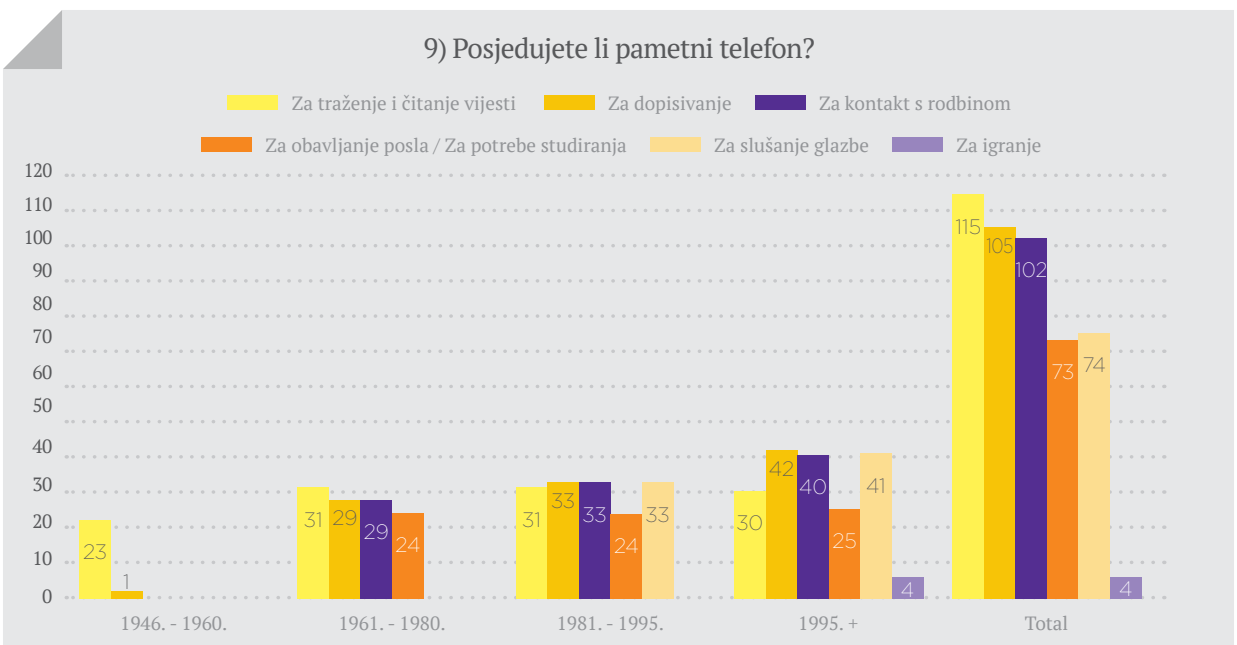

Grafikon 3. Način korištenja novih medija $(\mathrm{N}=152)$ 
Najpopularnije društvene platforme su Facebook i YouTube, a slijede ih Instagram i Twitter, kao i među mladima sve popularniji Snapchat koji je poznat isključivo Generaciji $\mathrm{Z}$ kojeg radije biraju zbog sve većeg broja starije populacije na ostalim društvenim mrežama, među kojima su i njihovi roditelji. Generaciji X, Y i Z zajednička je činjenica da za odlazak na društvene mreže pretežito, ili u slučaju ispitanika generacije $Z$, često koriste svoje pametne telefone za odlazak na društvene mreže.

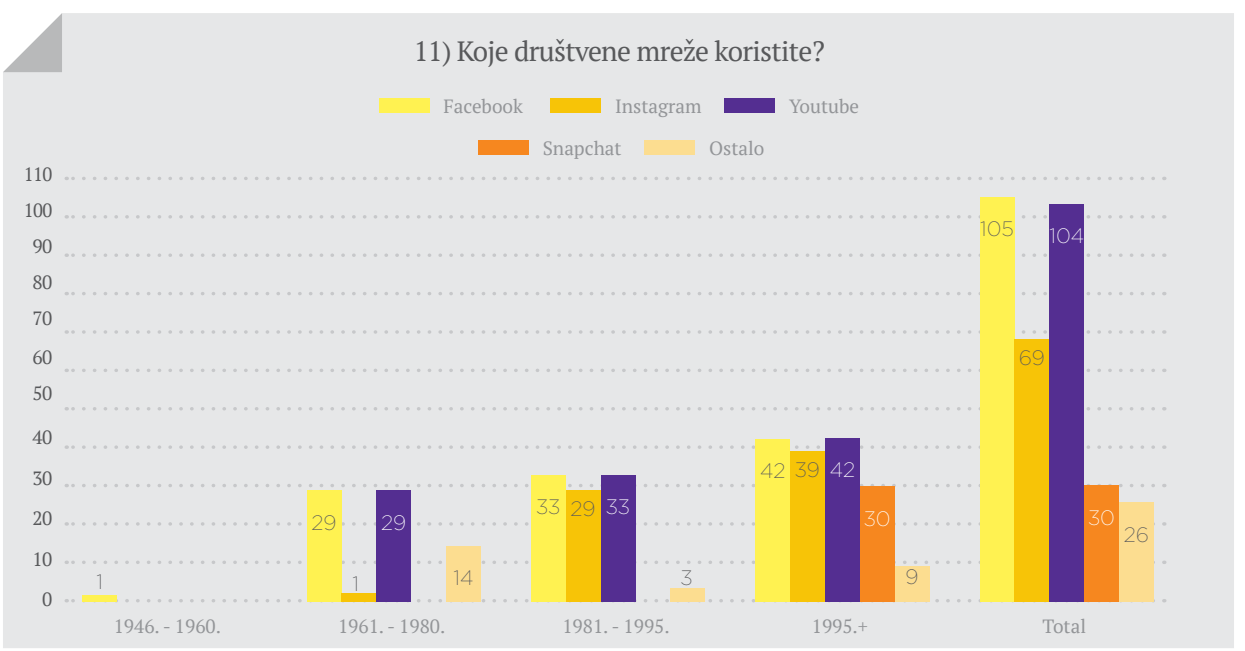

Grafikon 4. Društvene mreže po generacijskim kategorijama $(\mathrm{N}=152)$

S ispitanih 33 ispitanika pripadnika generacije Y i 42 ispitanika pripadnika generacije $\mathrm{Z}$, možemo zaključiti kako generacija $\mathrm{Z}$, iako ne mnogo, prednjači $\mathrm{u}$ provedenom vremenskom razdoblju na internetu. Generacija $Y$ većinom koristi internet $u$ svrhu posla ili obrazovanja, imajući tako status visokoobrazovane generacije. Možemo reći da su po uzoru na generaciju X pragmatičniji i praktičniji jer mudrije racionaliziraju svoje slobodno vrijeme. Budući da je generacija $\mathrm{Z}$ stalno dostupna drugim ljudima putem društvenih medija, možemo reći da zapravo ni nemaju slobodnog vremena. Jedino ta generacija od svih preostalih generacija nema granicu između virtualnog i stvarnog svijeta. Generacija Z koristi nove medije u sve, njima, potrebne svrhe - od obrazovanja i provođenja slobodnog vremena, poput druženja na društvenim mrežama ili slušanja glazbe, do uspostavljanja starih i novih kontakata ili svakodnevnog dopisivanja s najbližima. 
Generaciji Z pametni telefoni ne predstavljaju samo sredstvo komuniciranja i dopisivanja s bližnjima, oni koriste sve što današnje aplikacije omogućuju - da budu kalendari, podsjetnici, sredstva informiranja, fotoaparati i kamere, sredstva pomoću kojih uče s PowerPoint prezentacija, kao i uvid u njihove ocjene putem e-imenika. Shodno tome, logično je da su pripadnici generacije $\mathrm{Z}$ najčešći korisnici i posjetitelji internetskih servisa, foruma, blogova i društvenih mreža.

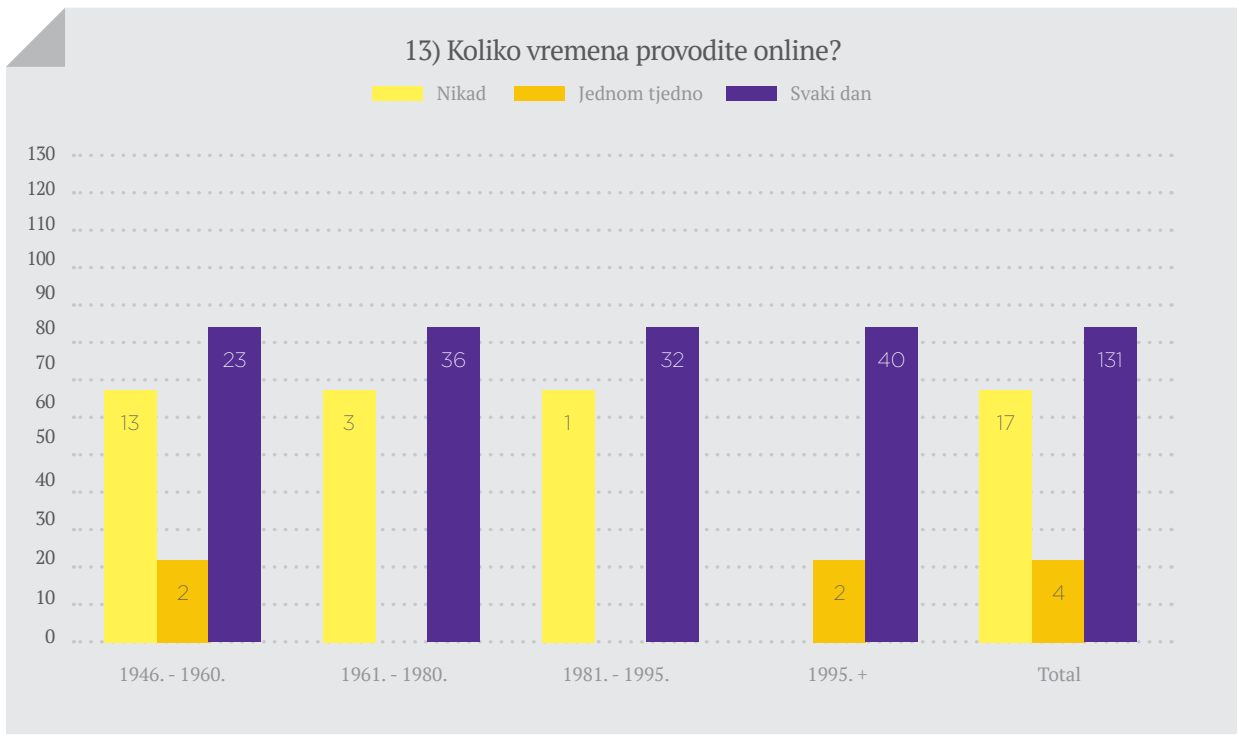

Grafikon 5. Vrijeme provedeno na internetu $(\mathrm{N}=152)$

Istraživanjem smo također htjeli provjeriti u kolikoj mjeri generacije koriste nove kanale dopisivanja - SMS poruke te aplikacije WhatsApp, Viber i Facebook Messenger. Budući da su se SMS poruke počele masovno koristiti tijekom 90-ih godina prošlog stoljeća, očekivano bejbibumersi i generacija $\mathrm{X}$ još uvelike koriste ovaj kanal za dopisivanje s bližnjima. Mlađe generacije, Y i Z, slabo ili uopće ne koriste SMS poruke. Svi ispitanici Z generacije koriste jednu od navedenih aplikacija za dopisivanje, dok su samo tri ispitanika generacije $Y$ rekla da ne koriste nijednu od tih aplikacija. Od 39 ispitanika generacije X, samo njih 15 koristi jednu od aplikacija. Posebno je zanimljiv dio istraživanja oko prepoznavanja različitih uređaja iz prošlosti sa slika priloženih uz anketna pitanja - prvi bežični telefon, VHS kazete, Commodore 64 - uređaj za diskete i walkman. 

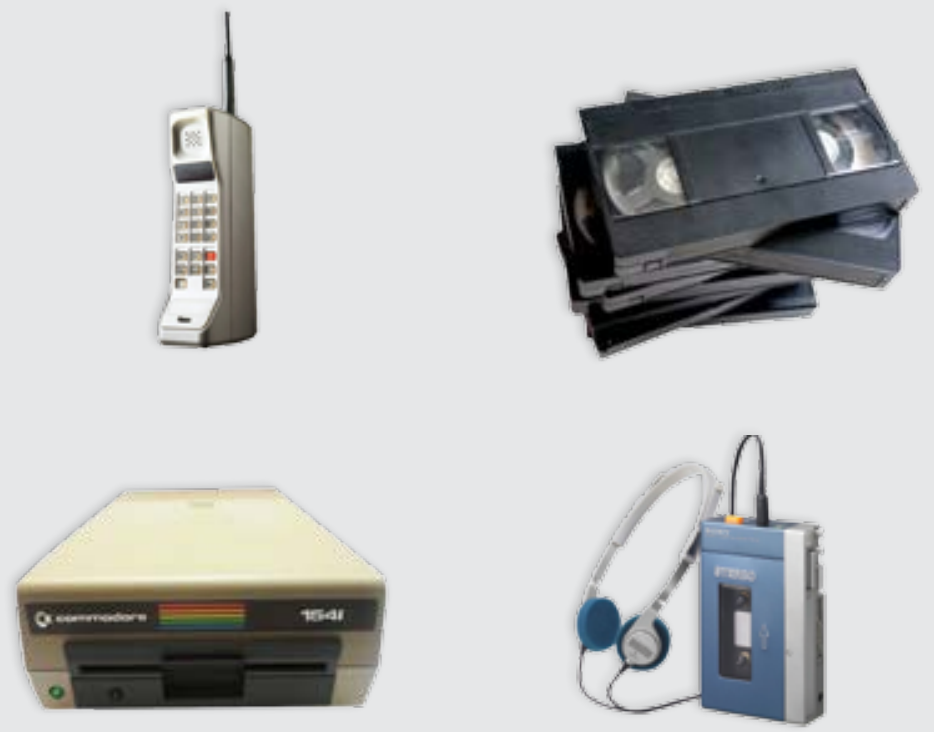

Slika 1. Prvi bežični telefon, VHS kazete, Commodore 64 - uređaj za diskete, walkman

Generacije X i Y prepoznaju gotovo sve uređaje, sami su ih koristili ili su ih koristili njihovi roditelji, dok velika većina pripadnika generacije $\mathrm{Z}$ ne prepoznaje određene uređaje, pogotovo posljednja dva prikazana - Commodore 64 i walkman. Upravo se po ovakvim primjerima vidi koliko brzo se odigrava smjena inovacija na tehnološkoj sceni koji u današnje doba zastarijevaju unutar nekoliko godina te su nadolazećim generacijama neprepoznatljivi.

\section{Zalključalk}

U ovom radu je vidljiv rast generacijskog jaza između generacijskih kategorija (od bejbibumersa do generacije Z) kao rezultat digitalizacije. U virtualnom svijetu novih tehnologija najbolje se snalaze generacije koje su rođene okružene tehnologijom, no problem se stvara kod starije generacije koja teže drži korak s tehnološkim napretkom. Stručnjaci se slažu oko činjenice da digitalni jaz treba suzbiti. Navodi se važnost politike 
i provođenja potrebnih reformi, posebice u školstvu. Nadalje, ističe se važnost samog interneta bez kojeg digitalno doba ne bi ni postojalo. Veliki problem je činjenica da samo trećina svjetskog stanovništva ima pristup internetu, a oni u udaljenijim i ruralnim krajevima najviše su pogođeni. Pokazalo je to i provedeno istraživanje u kojem su se pripadnici bejbibumers generacije izjasnili da ne posjeduju prijenosno računalo, nemaju pristup internetu te ni ne posjeduju osnovno znanje rada na računalu. Stoga je od velike važnosti da oprema i pristup internetu bude dostupna svima. Kao rješenje za taj problem u prvi plan se stavljaju digitalne knjižnice koje bi omogućite digitalnu povezanost svima i samim time suzbile digitalni jaz.

Također, zanimljivo je primijetiti kako ispitanici svakodnevno koriste dostupne društvene medije u slučaju da imaju potrebna sredstva i infrastrukturu. Može se lako zaključiti da kad osoba jednom upozna prednosti korištenja online servisa putem kojih si može olakšati svakodnevicu, počinje ih koristiti na dnevnoj bazi u različite svrhe. Pritom je osnovni zadatak svakog korisnika interneta držati raskorak između privatnog i virtualnog svijeta, oprezno dijeleći vlastite aktivnosti i podatke, bez obzira o kojoj se generacijskoj kategoriji radi, kao i paziti na vrijeme provedeno na internetu kako se ne bi naš stvarni i virtualni svijet spojili. Jasno je kako će ubrzo i generaciju Z zamijeniti generacija Alfa (buduće, tehnološki naprednije generacije), ali bitno je istaknuti povratak generacije $\mathrm{Z}$ tradicionalnim vrijednostima, proizašle upravo iz nesigurnosti i zbunjenosti svim dostupnim podacima koje ih okružuju. Iako je pohvalno imati sposobnost multitaskinga, nemoguće je ne primijetiti manjak koncentracije mlađih generacija uzrokovanom upravo zahtjevima za stalnom koncentracijom na više zadataka istovremeno.

Za pretpostaviti je kako će se i u budućnosti generacijski i digitalni jaz sve više produbljivati, ali ne smjenom generacija više desetljeća već, kako je u ovome radu navedeno, smjenom od svega nekoliko godina. Kako lako zaboravljamo donedavno najnovije tehnološke uređaje, tako će se sve brže odvijati smjena na sceni društvenih platformi kojih je trenutno na svijetu više od stotinjak. Bitno je samo znati prepoznati koje nam uistinu koriste i donose dobrobit i napredovanje u našim privatnim i poslovnim odnosima s drugim ljudima, kao i pravi način na koji ćemo se u budućnosti prezentirati svijetu. Na nama je da shvatimo koji su nam i u kojoj mjeri društveni mediji potrebni kako ne bismo, pokušavajući se što više povezati, (p)ostajali sve osamljeniji i udaljeniji od stvarnoga svijeta. 


\section{Popis literature}

- Aniko, V. (2015). Digital Gaps in School: Exploring the Digital Native Debate. Belvedere Meridionale.

- Castells, M. (1996). The information age: economy, society and culture, part 1: the rise of the network society. Oxford: Blackwell.

- Castells, M. (2000). The Rise of Network Society. Wiley: Blackwell.

- Castells, M. (2003). Internet galaksija. Zagreb: Naklada Jesenski i Turk.

- Christakis, N. A., Fowler, J. H. (2010). Povezani: iznenađujuća moć društvenih mreža i kako one utječu na naše živote. Zagreb: Algoritam.

- Enyon, R., Helsper, E. (2009). Digital Natives: where is the evidence? Londona: LSE.

- Gasser, U., Palfrey, J. (2008). Born digital. New York: Basic books.

- Lammiman, J., Syrett, M. (2005). Cool generacija: Nova poslovna filozofija. Zagreb: Ljevak.

- Krištofić, B. (2007). Digitalna nejednakost. Zagreb: Institut za društvena istraživanja u Zagrebu.

- Norris, P. (2001). Digital Divide: Civic Engagement, Information Poverty, and the Internet Worldwide. Cambridge: University Press.

- Parks, P. J. (2013). The Digital Divide. San Diego, CA.: Reference Point Press.

- Prensky, M. (2001). Digital Natives, Digital Immigrants. MCB University Press.

- Prensky, M. (2001). Digital Natives, Digital Immigrants, part II: Do they really think differently?. MCB University Press.

- Selwyn, N. (2009). The digital native - myth and reality. London: Emerald.

- Soar, J., Swindell, R., Tsang, P. (2011). Intelligent Technologies for Bridging the Grey Digital Divide. New York: Information science reference.

- Watson, I. R. (2013). Digital Natives or Digital Tribes? UK: Horizon Research Publishing.

- Zemke, R., Raines, C., Filipczak, B. (2000). Generations at Work: Managing the Clash of Veterans, Boomers, Xers and Nexterst in Your Workplace. New York: AMACOM.

- Berkep, S. B. (2014). Working with generations X and Y in Generation Z period: Management of different generation in business life. Mediterranean Journal of Social Science, 5 (19), 218-229.

- Grbavac, J., Grbavac, V. (2014). Pojava društvenih mreža kao globalnog komunikacijskog fenomena. Media, culture and public relations, 5 (2), 206-219.

- Kindrick Patterson, C. (2007). The Impact of Generational Diversity in the Workplace. The Diversity Factor, 15 (3), 17-22.

- Levickaitė, R. (2010). Generations X, Y, Z: How Social Networks Form the Concept of the World Without Borders (The Case of Lithuania). LIMES, 3 (2), 170-183.

- McNamara, S. A. (2005). Incorporating generational diversity. AORN Journal, 81 (6), 1149-1152.

- Montana, P. J., Petit, F. (2008). Motivating Generation X and Y on the Job and Preparing Z. Global Journal of Business Research, 2 (2), 139-148.

- Oh, E., Reeves, T. C. (2014). Generational differences and the integration of technology in learning, instruction, and performance, 819-828. U: Handbook of Research on Educational Communications and Technology: Fourth Edition. New York: Springer. 


\section{Internetski izvori}

- Businessinsider.com (2015). Here's who comes after Generation Z - and they'll be the most transformative age group ever. Dostupno na: http://www.businessinsider.com/generation-alpha-2014-7-2. Preuzeto 25. srpnja 2017.

- Eilers, L., Kindall, H., Crowe, T., Elsass, A. (2016). The Perceived Literacy Skills of „Digital Natives“ and „Digital Immigrants“in one Teacher Preparation program. Dostupno na: http://www.arareading.org/resources/Documents/Eilers,\%20et\%20 al_Digital\%20Natives\%20and\%20Digital\%20Immigrants.pdf. Preuzeto 25. srpnja 2017.

- HINA (2016). Broj korisnika interneta narastao u odnosu na prošlu godinu, no 52 posto stanovnika Zemlje još uvijek nema pristup. Dostupno na: http://www.jutarnji.hr/life/tehnologija/broj-korisnika-interneta-narastao-u-odnosu-na-proslugodinu-no-52-posto-stanovnika-zemlje-jos-uvijek-nema-pristup/4710407/. Preuzeto 25. srpnja 2017.

- Mason, R. M., Barzilai-Nahon, K., Lou, N. (2008). The Organizational impact of Digital Natives: How Organizations are Responding to the Next Generation of Knowledge Workers. Proceedings of the 17th International Conference on Management of Technology. Dostupno na: http://faculty.washington.edu/rmmason/Publications/IAMOT_DN_2008.pdf. Preuzeto 25. srpnja 2017.

- Raknić, D. (2016). Znate li u kojoj državi najviše koriste internet? Na samom dnu je diktatura Kim Jong-una, a hrvatske brojke iznenađuju... Dostupno na: http://www.jutarnji.hr/life/tehnologija/znate-li-u-kojoj-drzavi-najvise-koriste-internet-nasamom-dnu-je-diktatura-kim-jong-una-a-hrvatske-brojke-iznenaduju.../93829/. Preuzeto 25. srpnja 2017.

- Schawbel, D. (2014). 5 Predictions For Generation Alpha. Dostupno na: http://danschawbel.com/blog/5-predictions-forgeneration-alpha/. Preuzeto 28. srpnja 2017.

- OECD (2001). Understanding the digital divide. Dostupno na: http://www.oecd.org/dataoecd/38/57/1888451.pdf. Preuzeto 30. srpnja 2017. 


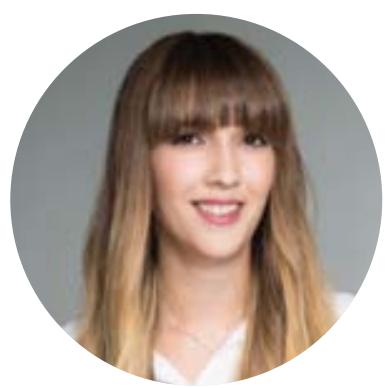

\section{Maja Fistrić}

Maja Fistrić rođena je 1988. u Zagrebu. Nakon završene osnovne i srednje škole upisuje studij komunikologije i povijesti na Hrvatskim studijima Sveučilišta $\mathrm{u}$ Zagrebu, te postaje magistra komunikologije i prvostupnica povijesti. Istovremeno upisuje Edward Bernays University College po čijem završetku stječe titulu stručne specijalistice za odnose s javnošću. Tijekom studiranja zapošljava se u Millenium promociji gdje je trenutno na poziciji Savjetnice za odnose $\mathrm{s}$ javnošću. Poseban interes pokazala je za proučavanje utjecaja medija i društvenih mreža na javnost, ponajviše djecu i mlade, te za implementaciju i širenje medijske pismenosti u Hrvatskoj. 